\title{
Comparing Knowledge and Usage of ICT among Male and Female Distance Learners of an Endowed and Deprived Area in a Developing Country in Africa
}

\author{
Olivia A. T. Frimpong Kwapong \\ University of Ghana, Legon - Accra, \\ Ghana, West Africa
}

\section{okwapong@ug.edu.gh}

\section{Executive Summary}

Distance learning in developing countries has emerged as a way of widening access to education for tertiary applicants who qualify but could not otherwise gain admission due to the limited space in the existing tertiary institutions. The delivery of the program in Ghana, a developing country in Africa, is predominantly print-based and is supported with regular face-to-face tutorials. In this process students face several challenges that could be supported with information and communication technology (ICT). The study looked at the extent to which, at their personal level, students utilize the few ICT facilities that are available in their localities that could form a basis for making a case for the use of interactive electronic platforms in the distance learning programs. The results revealed that both male and female learners have some access to and utilize ICT facilities. They have moderate knowledge and usage of the Internet. Distance learning institutions in developing countries could, therefore, take opportunity of this and gradually introduce some basic ICT applications such as e-mails, text messages, phone contacts, a website for providing detailed information, application and registration, uploading and downloading supplementary readers and other services to facilitate interaction among learners and the institutions. This way not only will quality be enhanced but also those in the remotest parts of developing countries could be conveniently reached.

Key words: Information and communication technology, distance learning, gender, Africa.

\section{Introduction}

The use of information and communication technology (ICT) for distance learning provides tremendous potential for meeting the goal of Education for All (EFA), which broadly seeks to meet the learning needs of children, youth, and adults by 2015. In 2000 the world re-affirmed its

Material published as part of this publication, either on-line or in print, is copyrighted by the Informing Science Institute. Permission to make digital or paper copy of part or all of these works for personal or classroom use is granted without fee provided that the copies are not made or distributed for profit or commercial advantage AND that copies 1) bear this notice in full and 2) give the full citation on the first page. It is permissible to abstract these works so long as credit is given. To copy in all other cases or to republish or to post on a server or to redistribute to lists requires specific permission and payment of a fee. Contact 0HPublisher@InformingScience.org to request redistribution permission. 1990's declaration of 'Education for All' to make a collective commitment to expand educational opportunities to groups in society, including girls and women. Participants at the World Education Forum in Dakar, Senegal, "endorsed a comprehensive vision of education, anchored in human rights, affirming the importance of learning at all ages and emphasizing the need for special measures to reach the poorest, most vul- 
nerable and most disadvantaged groups in society" (UNESCO, 2007, p. i). Among the six EFA goals is the goal to achieve gender equality by 2015. Like the Millennium Development Goals (MDGs), the achievement of all the six EFA goals depends to a large extent on the total empowerment of women whose role facilitates the capacity building of members of the family and the entire society. Meanwhile, the majority of women are in a marginalized position. A good number of them are located in some of the remotest parts of the world and largely affected by sociocultural factors which deprive them of full access to higher education. This has made it necessary to explore alternative ways of meeting the gender equality goal in education. One of such avenues is the use of ICTs for distance or technology-mediated learning. Robinson (2008) has noted that the use of distance education and ICT has the potential to distribute opportunities for learning more widely and equitably. ICT is thus a powerful tool for providing educational services for both males and females and, most importantly, meeting the gender equality goal. Studies have shown that ICTs offer possibilities to women especially to engage in not only distance learning programs but e-commerce, e-governance, and all other aspects of developmental activities (Bisnath, 2004; Daly, 2003; Huyer \& Sikoska, 2003; Kwapong, 2007c).

There is a wide gender gap in education at the tertiary level in Ghana, a developing country in Sub-Saharan Africa. The male-female ratio has hovered around 70-30 (NCTE, 2006). Several measures, such as establishment of more public and private tertiary institutions, expansion of facilities, and increment in enrolment quota for females, have been adopted. Though these efforts have helped to increase enrolment, the required result of 50-50 male-female ratio in higher education has not been achieved yet. To widen access to education and overcome the mismatch between the existing facilities and qualified applicants the Government has sought to promote distance learning among all professionals across gender and geographical locations for the past decade. The use of ICTs for distance learning makes the delivery more widely and evenly distributed than just reliance on printed materials. Meanwhile, probably as a result of limited technological infrastructural development, print has been the pre-dominant mode of delivery in the distance learning programs. This study looks at the extent to which students privately utilize the few ICT facilities that are available in their localities that could form a basis for making a case for utilization of ICT applications in the distance learning programs.

\section{Profile of Study Areas}

The study covers four out of the ten regions of Ghana. These include the three regions in the northern part of the country, known as Northern, Upper East and Upper West Regions (the deprived regions) and the Greater Accra Region (the endowed region). The three regions of the north are relatively deprived compared to Greater Accra Region, the national capital of the country. In the discussion of the results the three northern regions have been described as deprived and the Greater Accra Region has been described as endowed. Information from the Ministry of Local Government and Rural Development [MLGRD] (2006) and the Ghana Living Standards Survey 4 (GLSS 4, 2000) will be analyzed to give the regional profile.

\section{Northern Region}

Being the largest of the 10 regions of the country in terms of landmass, the Northern Region occupies 70,384 square kilometers which account for $29.5 \%$ of the total land area of Ghana. The population represents $9.6 \%$ of the country's population. The level of educational attainment in the region is low. The highest educational level of the majority of the people is primary school, for $43.6 \%$ of males and $53.5 \%$ of females. Only $22 \%$ of the population who are 15 years and older are classified as literate. With this low level of literacy, general interest in ICT protocols in the region could be very low. The level of education has affected economic activities as well. Agriculture, hunting, and forestry are the main economic activities in the region. Thus the majority of 
the people operate in the informal sector which leads to a high incidence of poverty in the region (Ghana, 2003).

Compared to other parts of the country, the infrastructure development is low. The kerosene lamp is the major source of lighting, while $22 \%$ use electricity. This low coverage of electricity could no doubt influence access to Internet facilities, television and radio and other information that may have direct impact on health, education, economic, and other developmental activities. There is also a limited availability of Post Office facilities in the region. Due to the lack of an information technology network backbone, access to phones in the region is very limited.

\section{Upper East Region}

Population of the region is primarily rural $(84.3 \%)$ and scattered in dispersed settlements. Only $15.7 \%$ of the population lives in urban areas. The majority of the people live in huts built of mud and roofed with straw or corrugated iron sheets. Illiteracy is $78.1 \%$.

As a result the majority operate in the informal sector such as agriculture and related work $(65.9 \%)$, production and transport equipment work (14.5\%) and others.

Infrastructure development that could facilitate the provision of ICT services is minimal in the region. Postal services are only available in large settlements. Linkages of district capitals are poor and in some cases are not operational. There are some private communication centers that serve some communities. Phones per 100 populations are 0.1 in the region. About 13 towns are on the national electricity grid. The poor levels of education and income and limited availability of basic infrastructure that could support ICT will impact on the access to and utilization of ICT facilities in the region especially for women who are faced with several socio-cultural inhibitions (Daly, 2003).

\section{Upper West Region}

Upper West Region has only $17.5 \%$ of its total population living in urban localities. Regarding education, $69.8 \%$ of the population aged 6 years and older has never attended school, and $73.9 \%$ of this $69.8 \%$ are females. The majority of the educated population completed primary and Middle/Junior Secondary School forming 68.9\%. Just like the two other regions in the north, the major occupations in the region are agriculture and related work (72\%), production and transport equipment work (12.1\%), sales work (5.2\%), service work (4.0\%), and professional, technical and related work $(4.0 \%)$. Infrastructure development in the region is not very much different from the two other regions, which will make their access to and utilization of ICT facilities very minimal.

\section{Greater Accra Region}

The Greater Accra Region, which is the capital region of Ghana, is the smallest of the 10 administrative regions in terms of area. The region occupies $1.4 \%$ of the total land area of the country. In terms of population it is the second most populated region, having $15.4 \%$ of the total population. Unlike the three regions of the north, literacy is relatively high (78.2\%). Economic activities of the people are not predominantly agriculture but rather sales and service (42\%), professional, technical and related workers $(10.8 \%)$, and others.

Infrastructure development is relatively high in this region. Electricity is used by more than three quarters of households for lighting. Post office facility ranges from $1.3 \%$ to $8.8 \%$. Telephone facility is available in all the districts. In the Accra Metropolitan Area, telephone facility is available in all the communities and the distance to the nearest facility is less than 1 kilometer. Again, as the national capital, the region is covered by all the telephone operators in the country. 
The data on the various regions has revealed that the Greater Accra Region is ahead of the three northern regions in terms of educational attainments, infrastructure development, and employments. As the state capital region most of the resources and employment opportunities are available, which could make life relatively better. This will possibly give the distance learners an advantage over their counterparts in other regions in relation to access to and utilization of ICT facilities.

\section{Distance Learning in Ghana}

As a result of limited space and a mismatch between qualified applicants and existing facilities, a high percentage of qualified applicants do not gain admission to existing universities to pursue further studies. For instance, during the 2005/2006 academic year, a little over half (55\%) of qualified applicants were admitted into all the public universities. The situation is even worse for women. During the same period the male to female enrolment ratio was 65:35 for the universities (NCTE, 2006).

The disparity begins at the secondary school level through to tertiary level. Statistics on education indicate that only about $30 \%$ of Junior High School (JHS) graduates are able to gain admission to Senior High School (SHS), and only about $35 \%$ of SHS graduates are able to gain admission to universities and polytechnics, plus another $10 \%$ to $20 \%$, to diploma-level post-secondary education. Private secondary schools are not many so they are able to enroll only a minimal number of qualified applicants. At the tertiary level about 5,000 undergraduates are enrolled in secular degree-granting programs in the existing nine private institutions (Ghana, n.d.).

In response to the situation, the Government of Ghana has long explored the need to use distance learning to respond to the educational needs of the large number of qualified applicants, especially at the tertiary level. This is highly emphasized in the country's most recent educational policy in which the Government seeks to establish an open university and set up community open colleges in all the regions.

A distance education policy of the Ministry of Education outlines that distance education (DE) programs be provided to:

- increase access to and participation in education of all types and at all levels for all.

- facilitate progression through the education system.

- improve people's capacity to cope with rapid changes in knowledge and skills and thereby improve upon their contribution to the economy and society.

- increase equality and democratization of education.

- make education cost-effective and affordable. (Mensah \& Owusu-Mensah, 2002)

Currently four of the public universities, University of Ghana (UG), University of Cape Coast (UCC), Kwame Nkrumah University of Science and Technology (KNUST), and University of Education, Winneba (UEW), are offering their academic programs in a dual mode. The programs are being patronized greatly by both males and females in the country, and characteristic of most distance learning institutions the percentage of female enrolment is rather different from that of on-campus programs. In the on-campus programs the percentage of female enrolment has ranged from $27 \%$ to $35 \%$ since 2000 (NCTE, 2006). Meanwhile statistics of the various distance education institutions indicate that UEW which began its distance learning program in 1998 has approximately 7000 students with 53\% females and 46.5\% males at its Level 300 for the 2006/7 school year. UCC, which began its distance education program in 2001, has over 18,000 students, $49.7 \%$ females and $50.2 \%$ males in the Dip. Ed. distance education courses. 
The distance education programs that are being offered are mainly print-based supported with occasional face-to-face tutoring where students meet their tutors at a center for discussions. Assignments are either hand delivered or mailed by post. Students meet at a designated center to write their end of semester examinations. In cases where course materials are not ready, lecturers either meet to lecture the students in the various centers or students join the on-campus lectures. DE students also share the already over-stretched facilities, such as libraries, with the on-campus students. Much as these educational processes create opportunity for those who will otherwise not gain admission to pursue their life dream education, it presents enormous challenges to the DE institutions and the learners as well.

Traveling to centers for tutorials or lectures will not only expose learners and students to the risks of highway robbery and accident but may also not be cost effective for the institution and the student as well. A continuous practice of regular travels to centers for tutorials may make the programs lose their distance learning philosophy and probably turn to be a face-to-face education program. In this case learners may be forced to leave their jobs more often and those who cannot afford to leave the workplace or cannot obtain permission may drop out of the program.

Considering DE as a mode that meets women's lifestyle because they can conveniently work, keep their homes, and study, excessive use of face-to-face interactions may not be convenient for them. For some women, obtaining permission from their husbands could be more challenging than obtaining permission from the workplace (Kwapong, 2007c).

These are challenges that most countries, especially those in the developed world, have used ICT to overcome. The rapid advancement in information technology has dictated the pace of growth of correspondent education to distance education and now online learning, e-learning, virtual university, or technology-mediated learning. With the advancement, the distance and isolation in the distance learning system has been overcome to a very large extent.

The next section will focus on the use of ICT for distance learning and its implications for a developing country such as Ghana. Currently, the available technologies in Ghana have been estimated to be 356,400 telephone lines, 5,207 mobile cellular phones, zero AM, 49 FM, 3 shortwave radio broadcast stations, and 7 television broadcast stations. It is estimated that Internet hosts of 2,899 could now join in the information transfer for 609,800 Internet users (Infoplease, n.d; Ghana, n.d; Ghana, 2003).

\section{ICT for Distance Learning in Ghana}

The widely used acronym ICT has been described to encompass a multitude of equipment, software, and services. It can be broadly interpreted as technologies that facilitate communication and the processing and transmission of information by electronic means. This definition encompasses the full range of ICTs, from radio and television to telephones (fixed and mobile), computers, and the Internet. In development contexts, the interface with traditional communication systems and tools is also important for applications in areas such as agriculture, business, governance, health, and education (GenARDIS, n.d.). Similarly, Primo (2003, p. 9) explains that "ICTs are understood to include computers, the rapidly changing communications technologies including radio, television, mobile telephony and Internet, networking and data processing capabilities, and the software for using the technologies." ICTs provide the capacity to harness, access, and apply information and disseminate knowledge in all kinds of human activities. These have created the opportunity to improve the quality of daily life and education. There is a misperception that ICTs are only useful for middle income and developed countries. Recent research suggests that poor citizens from low income countries could benefit dramatically from having access to telephony and the Internet (World Bank, n.d.). New types of economic and employment opportunities like e-commerce, new educational modalities such as distance learning and on-line training, and pos- 
sibilities to access institutions of governance using online access to information, are just few of the opportunities emerging as a result of the use and application of ICTs in development (Hafkin, 2003; Koul \& Kanwar, 2006).

Research has shown that distance learning supported with ICT meets the learning style of women and, for that matter, widens access to education for them (Bisnath, 2004; Daly, 2003; Kwapong 2007c). Meanwhile there are arguments over the use of ICTs for empowerment of women, especially in the third world. It is argued that women in the Third World have more pressing needs, such as safe water, adequate food, improved health, and better education, than access to ICTs. This bread or computers argument can no longer hold. It has been counter argued that health, water, food, education, and ICTs are not in opposition to each other. ICTs could rather be used to facilitate the process through equitable and affordable access. Those who defend the potential of ICTs for development and most especially for empowerment of women argue that women no longer have the luxury to ignore ICTs and the globalization of information and economies which are carried by ICTs (Bisnath, 2004; Daly, 2003; Huyer \& Sikoska, 2003; Kwapong, 2007a, $2007 b$ ). This does not imply that ICTs are a panacea for development or a replacement for real world needs. The continuous development of new technologies and their applications could enhance the quality of life for all, irrespective of the geographical location and gender.

In the light of the realities on the ground in developing countries, Gulati (2008) has argued that lack of resources, including buildings, desks, books, and qualified teachers, has been a significant obstacle for open and distance learning. The author questions what new ICTs could do to raise the status and quality of distance education in developing countries and whether ICTs benefit those who are resource poor and have limited or no access to paper-based modes of distance education delivery. A review of 150 distance education programs in sub-Saharan Africa has revealed that the print mode continues to be more reliable, sustainable, and widely used than online and Webbased methods of learning. This could be as a result of limited ICT infrastructural development and unreliability of electricity in most parts of the sub-region. Gulati is quick to add that this does not, however, imply that developing countries with limited infrastructure should not use online learning methods.

Technology-mediated learning has the potential to meet the educational needs of masses of poor people in developing countries. E-learning could offer the opportunity to shift the distance learning paradigm from delivery of content towards learner-centered and discussion-led learning. It is a challenge, therefore, in developing countries to educate students and teachers to use computers and develop accessible infrastructure so that they may benefit from the interactivity offered by online learning. Again considering the sparse nature of most communities in the developing world and the poor road networks which inhibit people to travel easily to and fro, ICTs that overcome time and space could be a more appropriate way of connecting people across different geographical areas. A living case is the rapid growth in the use of mobile phone telephony in even the remotest parts of the developing world, including farmlands. The world is fast becoming a global village, and as a possible tool for facilitating development, the developing world cannot afford not to be part of the ICT revolution. Though ICT use is capital intensive it could be a tool for poverty alleviation in terms of knowledge sharing and skills building. Investment in ICT to bridge the digital divide will no doubt lead to bridging the economic and gender divides as well. One way out is to implement policies for basic and primary educational infrastructure to support low-cost but higher quality access in rural and deprived areas (Asraf, Swatman, \& Hanisch, 2007; Bruce, Hagens, \& Ellis, 2007; Denison \& Johanson, 2007; Holloway \& Savvina, 2008; James, Leinonen, Smith, \& Haataja 2006; Kyama \& Waititu, 2008; "North West women," 2008; Robinson, 2008; Sales, Al-Barwani, \& Miske, 2007; Siaciwena \& Lubinda, 2008). 
Current studies reveal that the ICT situation in the developing world is improving, especially in the area of mobile telephony, though broadband is still a challenge. A report by ITU (2007) gives a detailed update of the current situation of ICT in both the developed and the developing worlds. The report indicates that the digital divide is shrinking in most technologies, especially mobile telephony, but limitations in the availability and affordability of broadband remain a cause for concern. Developing countries are gaining on OECD countries in terms of fixed line penetration, mobile cellular subscriber penetration, Internet usage, and broadband penetration. Least Developed Countries (LDCs) are also catching up with developing countries in terms of mobile phones, Internet usage, and broadband. Low-income countries are making important gains in mobile telephony, with mobile phones outnumbering fixed lines by seven to one in LDCs, and by as much as nine to one in Sub-Saharan Africa, which is a good example of technological leapfrogging. In some developed markets, consumers are cutting the cord and increasingly opting for mobile phone ownership rather than fixed lines. ITU has estimated that by the end of 2008, more than half the world's population is expected to have access to mobile phones.

The report by ITU observes that the impact of mobile phones in reducing the digital divide is most remarkable in Africa, where the number grew from just 15 million in 2000 to over 160 million by the end of 2006. In a continent that is poorly served with fixed line infrastructure, mobile phones are now the primary medium for electronic communications. Much of the new investment is coming from companies based in Africa itself. The digital divide is also narrowing in terms of Internet usage. Considering the cost and the infrastructural requirements for using some ICT facilities, mobile telephony will be endorsed as having a huge potential in the low-income countries, accounting for over a third of the world's population but just $8 \%$ of the world's mobile subscribers.

ICT is of special relevance for the delivery of distance learning in several ways, most especially in a developing country such as Ghana. Gulati (2008) observes that new communication technologies, particularly the Internet, appear to offer exciting possibilities for overcoming geographical access and cost barriers to learning. Robinson (2008) also observes that the use of distance education and ICT has the potential to distribute opportunities for learning more widely and equitably for people of different professions. Distance education and ICT have the capacity for large-scale delivery over huge distances and this is where development workers should focus. Knowledge and usage of ICT facilities among distance learners in Ghana was tested to check the extent to which learners in both endowed and deprived regions of the country are privately utilizing the few existing facilities and the way forward.

\section{Survey Methodology}

This survey sought to find out the ICT situation, most specifically with reference to knowledge and usage, in the most endowed and deprived regions of the country. The population for the study was distance learners of the University of Ghana Distance Education Program who are scattered all over the country. The learners were pursuing a first degree program. The purpose was simply to test the knowledge and usage of basic ICT facilities, such as the Internet, search engines like Google, and ownership of ICT facilities, and to find out how much users invest and are willing to further invest in such services to support their studies at a distance. Respondents were, therefore, asked simple questions on knowledge of ICT, where they access the Internet, duration of browsing, usage of the search engines, and amount paid for the services. Specific questions included the following: Do you know what ICT is? Do you use the Internet café? Where do you access the Internet? How long on average do you stay on the Interne? How many times per week do you use the café? How much do you pay per hour? What do you use the Internet for? Do you know that the Internet could be used to access educational materials? Are you aware of search engines such as Google that you can use to access web sites? How often do you use the search engines per 
week? Are you aware that ICT can enhance your knowledge in any area of your choice? Do you own a personal computer? Would you like to own one? Would you pay a flat fee of GH $\phi 20-30$ (approximately US\$20-30) per month for Internet connection? Would you want to have Internet connection at your school, work or home? Focus was on the Internet for two reasons. First, it has a high potential for promoting technology-mediated learning and reaching out to those in the remotest part of the world. Second, the author assumed that respondents could have a relatively high level of awareness about the Internet, which could enable them to relate to the issues and provide some responses. Introducing an unfamiliar ICT application could make it impossible to obtain responses if no sensitization was undertaken.

To test for validity and reliability of the survey instrument, the first draft of the questionnaire was administered to 40 students ( 20 males and 20 females) who were not part of the respondents. This helped to obtain feedback that was used to revise the final instrument. The instrument was administered to the respondents during one of their face-to-face tutorials at their study centers. There is one study center per region. At the study centers, the number of male and female respondents was randomly selected for the data collection.

A sample of 400 respondents (200 males, 200 females) from both the endowed and deprived regions of Ghana was selected for the study. Forty students did not fully complete the questionnaire so a total of $360(90 \%)$ responses were counted as received from174 (48.3\%) females and 186 $(51.6 \%)$ males, indicating a higher response from the males than the females. Out of the $174 \mathrm{fe}-$ males, $54(31 \%)$ responses were obtained from the Greater Accra region, the capital region of Ghana which is relatively well endowed compared to the other regions of the country, and 120 $(68.9 \%)$ from the three northern regions (the deprived regions), which include Northern Region, Upper West Region and Upper East Region. For the males, 83 (44.6\%) responses were obtained from Greater Accra Region and 103 (55.3\%) from the three regions of the north. The responses were analyzed using percentages and chi-square.

\section{Results}

\section{Demographics of Respondents}

From the demographic results of the survey, the majority of the respondents (72.8\%) fell within the age range of $20-30$ years. Probably reflecting their age, a higher percentage of $73.9 \%$ were not married, with only $12.4 \%$ indicating that they were married. The rest did not declare their marital status. This is an indication that the majority of the respondents were in their early adult stage and could be young professionals or in the process of deciding on a profession. This age group could have a relatively higher level of curiosity and be interested in ICT systems. In terms of education, more than half (56.9\%) indicated that they had completed secondary level education and the rest had obtained diploma and other certificates. On professional background of the respondents, $33 \%$ were teachers, followed by those in the informal sector $(11 \%)$, and then civil servants $(8 \%)$. A total of $28.7 \%$ indicated that they were full time students.

\section{Knowledge and Usage of ICT}

Knowledge of ICT appeared to be relatively high among all the respondents. Table 1 below provides the comprehensive results. In total, $77.5 \%$ of the respondents indicated that they knew what ICT is. A regional breakdown revealed that $69.5 \%$ of the respondents in the three northern regions and $90.5 \%$ of the respondents from Greater Accra region knew ICT. On gender lines, $80.6 \%$ of the men in northern Ghana as against $91.6 \%$ of the men in Greater Accra region responded that they knew what ICT is, while $60 \%$ of the women in the three regions and $88.9 \%$ of the women in Greater Accra region knew ICT. The regional and gender breakdown revealed that 
knowledge of ICT is relatively higher in the most endowed region, Greater Accra, than the deprived regions. Another significant observation is that at the regional level there is a high gender difference in the deprived regions than the endowed regions. The chi-square results revealed that there is a significant relationship between sex and knowledge of ICT $\left(x^{2}=14, \mathrm{df}=1, \mathrm{p}=0.00\right)$. A bigger number of the respondents who answered "Yes" to knowledge of ICT were males; whereas, a bigger number of respondents who answered "No" were females. This could lead to the conclusion that males are more knowledgeable about ICT than females. However, though in the gender totals the male percentage was higher than the female percentage $(85.5 \%$ males and $69 \%$ females), the regional disaggregated results reveal that the percentage of females from the endowed region who knew what ICT is, is higher than the males in the deprived areas. In this case one may not see gender as the only inhibiting factor but probably the issue of exposure and availability of ICT facilities and other resources.

\section{Table 1: Knowledge of ICT by sex and region}

Region * Do you know what ICT is? Crosstabulation

\begin{tabular}{|c|c|c|c|c|c|c|}
\hline \multirow[b]{2}{*}{ Sex } & & & & \multicolumn{2}{|c|}{$\begin{array}{c}\text { Do you know what ICT } \\
\text { is? }\end{array}$} & \multirow[b]{2}{*}{ Total } \\
\hline & & & & Yes & No & \\
\hline \multirow[t]{6}{*}{ Male } & Region & Northern & Count & 83 & 20 & 103 \\
\hline & & & $\%$ within Region & $80.6 \%$ & $19.4 \%$ & $100.0 \%$ \\
\hline & & Greater Accra & Count & 76 & 7 & 83 \\
\hline & & & $\%$ within Region & $91.6 \%$ & $8.4 \%$ & $100.0 \%$ \\
\hline & Total & & Count & 159 & 27 & 186 \\
\hline & & & $\%$ within Region & $85.5 \%$ & $14.5 \%$ & $100.0 \%$ \\
\hline \multirow[t]{6}{*}{ Female } & Region & Northern & Count & 72 & 48 & 120 \\
\hline & & & $\%$ within Region & $60.0 \%$ & $40.0 \%$ & $100.0 \%$ \\
\hline & & Greater Accra & Count & 48 & 6 & 54 \\
\hline & & & $\%$ within Region & $88.9 \%$ & $11.1 \%$ & $100.0 \%$ \\
\hline & Total & & Count & 120 & 54 & 174 \\
\hline & & & $\%$ within Region & $69.0 \%$ & $31.0 \%$ & $100.0 \%$ \\
\hline
\end{tabular}

Following the above was the question on usage of the Internet. Respondents were asked whether they use the Internet. The study showed that $63.3 \%$ of all the respondents indicated that they use the Internet. Across regions, $46.7 \%$ of the respondents from northern Ghana as against $90.6 \%$ from the Greater Accra region responded that they use the Internet. In relation to gender, $91.6 \%$ of the men from the endowed region and $58.7 \%$ of the men from the deprived regions, forming a total of $73.3 \%$ of the men, and $89.1 \%$ of the women from the endowed regions and $36.6 \%$ of women from the deprived regions, forming a total of $52.8 \%$ of the women, indicated that they use the Internet. In correspondence with the results on knowledge of ICT, the results on the usage of Internet also shows that a high percentage of both males and females from the endowed region use the Internet as compared to their counterparts in the deprived areas. Again one may perceive that it is probably not only an issue of gender, but also access to or availability of ICT facilities and resources that is determining the usage of ICT facilities such as the Internet.

To probe further into available sources for accessing the Internet, respondents accessing the Internet were asked where they access it. The results as presented in Table 2 show that the office, home and Internet café emerged as the major places where respondents get access. In both the endowed and deprived areas, the Internet café emerged as the major sources where both male and female respondents access the Internet. This was followed by the office and then the home. It is 
interesting to note that for those who access the Internet from the office, café, and home, females from the endowed region topped the list with $16.3 \%$, followed by $11.3 \%$ of males from the deprived regions, $5.4 \%$ of males from the endowed regions, and $2.2 \%$ of females from the deprived regions.

Table 2: Location of Internet access

Region * If yes, where do you access the Internet? Crosstabulation

\begin{tabular}{|c|c|c|c|c|c|c|c|c|}
\hline \multirow[b]{2}{*}{ Sex } & & & & \multicolumn{4}{|c|}{ If yes, where do you access the Internet? } & \multirow[b]{2}{*}{ Total } \\
\hline & & & & Home & Office & Internet Cafe & $\begin{array}{l}\text { All of the } \\
\text { above }\end{array}$ & \\
\hline \multirow[t]{6}{*}{ Male } & Region & Northern & Count & 1 & 6 & 48 & 7 & 62 \\
\hline & & & $\%$ within Region & $1.6 \%$ & $9.7 \%$ & $77.4 \%$ & $11.3 \%$ & $100.0 \%$ \\
\hline & & Greater Accra & Count & 3 & 11 & 56 & 4 & 74 \\
\hline & & & $\%$ within Region & $4.1 \%$ & $14.9 \%$ & $75.7 \%$ & $5.4 \%$ & $100.0 \%$ \\
\hline & Total & & Count & 4 & 17 & 104 & 11 & 136 \\
\hline & & & $\%$ within Region & $2.9 \%$ & $12.5 \%$ & $76.5 \%$ & $8.1 \%$ & $100.0 \%$ \\
\hline \multirow[t]{6}{*}{ Female } & Region & Northern & Count & 2 & 10 & 32 & 1 & 45 \\
\hline & & & $\%$ within Region & $4.4 \%$ & $22.2 \%$ & $71.1 \%$ & $2.2 \%$ & $100.0 \%$ \\
\hline & & Greater Accra & Count & 1 & 7 & 33 & 8 & 49 \\
\hline & & & $\%$ within Region & $2.0 \%$ & $14.3 \%$ & $67.3 \%$ & $16.3 \%$ & $100.0 \%$ \\
\hline & Total & & Count & 3 & 17 & 65 & 9 & 94 \\
\hline & & & $\%$ within Region & $3.2 \%$ & $18.1 \%$ & $69.1 \%$ & $9.6 \%$ & $100.0 \%$ \\
\hline
\end{tabular}

One other surprising observation is that among those who access the Internet from only the office, the women from the deprived regions were leading with $22.2 \%$ followed by the men from the endowed region $(14.9 \%)$, and then women from the endowed region (14.3\%) before men from the deprived region $(9.7 \%)$. The entire results, as detailed in Table 2, give an interaction of both gender and location. Much as gender came out strongly in terms of accessing the Internet from the office and all of the places mentioned, it is neither gender nor location that came out strongly as the determining factor. Maybe it is a matter of availability and convenience. Probably the women in the deprived regions who emerged as forming the highest percentage of those accessing the Internet from only the office was as a result of availability of the facility and time in their offices. This confirms that given the availability of ICT facilities and required resources, gender may not be an inhibiting factor for accessing the Internet.

Time spent on the Internet was also tested. As detailed in Table 3, results varied across location and gender. Among those who could stay on the Internet for up to an hour and a half, the men from the three northern regions were leading with $48.4 \%$, followed by men from the endowed $(37.3 \%)$, then women from the endowed region (30.6\%), and lastly women from deprived regions (26.7\%). Meanwhile for those who could stay on the Internet for up to just thirty minutes, women from the deprived regions were on top with $55.6 \%$, followed by women from the endowed region $(28.6 \%)$ and the men, who formed $19 \%$. Time, gender, location, and probably resources are all at play in these results: the lesser time more of the females were able to stay on the Internet and the longer period more of the males were able to stay on the Internet. The situation is worse for women from the deprived regions, none of whom could stay on the Internet for over two hours, while their counterparts in the endowed region formed the highest percentage of those who could stay on the Internet for over two hours. A follow up question to find out the determining factors would have been helpful, but one could assume that since women have competing demands on their time for work, child, and home care, and probably with limited financial resources, they cannot afford to stay on the Internet for too long a time. But for men who do not have as much of a constraint in terms of time and finance, they could afford to stay longer on the Internet. 
Table 3: Length of time on the Internet

\begin{tabular}{|c|c|c|c|c|c|c|c|c|c|}
\hline \multicolumn{10}{|c|}{ Region * If Yes, how long on average do you stay on the Internet? Crosstabulation } \\
\hline \multirow[b]{2}{*}{ Sex } & & & & \multicolumn{5}{|c|}{ If Yes, how long on average do you stay on the Internet? } & \multirow[b]{2}{*}{ Total } \\
\hline & & & & Up to $30 \mathrm{~min}$ & 31 to $59 \mathrm{~min}$ & $\begin{array}{c}1 \text { hour- } 1 \mathrm{hr} \\
30 \mathrm{~min}\end{array}$ & $\begin{array}{c}1 \mathrm{hr} 31 \\
\text { min-2hrs }\end{array}$ & Above $2 \mathrm{hrs}$ & \\
\hline \multirow[t]{6}{*}{ Male } & Region & Northern & Count & 11 & 10 & 30 & 6 & 5 & 62 \\
\hline & & & $\%$ within Region & $17.7 \%$ & $16.1 \%$ & $48.4 \%$ & $9.7 \%$ & $8.1 \%$ & $100.0 \%$ \\
\hline & & Greater Accra & Count & 15 & 9 & 28 & 13 & 10 & 75 \\
\hline & & & $\%$ within Region & $20.0 \%$ & $12.0 \%$ & $37.3 \%$ & $17.3 \%$ & $13.3 \%$ & $100.0 \%$ \\
\hline & Total & & Count & 26 & 19 & 58 & 19 & 15 & 137 \\
\hline & & & $\%$ within Region & $19.0 \%$ & $13.9 \%$ & $42.3 \%$ & $13.9 \%$ & $10.9 \%$ & $100.0 \%$ \\
\hline \multirow[t]{6}{*}{ Female } & Region & Northern & Count & 25 & 6 & 12 & 2 & 0 & 45 \\
\hline & & & $\%$ within Region & $55.6 \%$ & $13.3 \%$ & $26.7 \%$ & $4.4 \%$ & $.0 \%$ & $100.0 \%$ \\
\hline & & Greater Accra & Count & 14 & 7 & 15 & 6 & 7 & 49 \\
\hline & & & $\%$ within Region & $28.6 \%$ & $14.3 \%$ & $30.6 \%$ & $12.2 \%$ & $14.3 \%$ & $100.0 \%$ \\
\hline & Total & & Count & 39 & 13 & 27 & 8 & 7 & 94 \\
\hline & & & $\%$ within Region & $41.5 \%$ & $13.8 \%$ & $28.7 \%$ & $8.5 \%$ & $7.4 \%$ & $100.0 \%$ \\
\hline
\end{tabular}

Table 4 shows that frequency of usage of the café per week was higher among the men than the women. While $38 \%$ of the men and $34.1 \%$ of all the women indicated that they use the café once a week, $22.2 \%$ of the men and $17.6 \%$ of all the women indicated that they use the cafe thrice a week. Using an Internet café attracts a fee so probably, unlike women who will prefer to invest their main or surplus income in food and other domestic requirements, men could conveniently put some money into Internet services. This could probably explain why women choose to utilize more of the Internet facilities in their offices, which may be free.

Table 4: Use the Internet Café

\begin{tabular}{|c|c|c|c|c|c|c|c|c|c|}
\hline \multirow[b]{2}{*}{ Sex } & & & & \multicolumn{5}{|c|}{$\begin{array}{l}\text { If Yes, How many times per week } \\
\text { do you use the cafe? }\end{array}$} & \multirow[t]{2}{*}{ Total } \\
\hline & & & & $\begin{array}{l}\text { Occa- } \\
\text { sional }\end{array}$ & Once & Twice & Thrice & $\begin{array}{l}\text { More } \\
\text { than } \\
\text { Thrice }\end{array}$ & \\
\hline \multirow[t]{6}{*}{ Male } & Region & Northern & Count & 1 & 25 & 15 & 14 & 4 & 59 \\
\hline & & & $\%$ within Region & $1.7 \%$ & $42.4 \%$ & $25.4 \%$ & $23.7 \%$ & $6.8 \%$ & $100.0 \%$ \\
\hline & & G. Accra & Count & 2 & 23 & 16 & 14 & 12 & 67 \\
\hline & & & $\%$ within Region & $3.0 \%$ & $34.3 \%$ & $23.9 \%$ & $20.9 \%$ & $17.9 \%$ & $100.0 \%$ \\
\hline & Total & & Count & 3 & 48 & 31 & 28 & 16 & 126 \\
\hline & & & $\%$ within Region & $2.4 \%$ & $38.1 \%$ & $24.6 \%$ & $22.2 \%$ & $12.7 \%$ & $100.0 \%$ \\
\hline \multirow[t]{6}{*}{ Female } & Region & Northern & Count & 1 & 13 & 19 & 8 & 2 & 43 \\
\hline & & & $\%$ within Region & $2.3 \%$ & $30.2 \%$ & $44.2 \%$ & $18.6 \%$ & $4.7 \%$ & $100.0 \%$ \\
\hline & & G. Accra & Count & 3 & 16 & 9 & 7 & 7 & 42 \\
\hline & & & $\%$ within Region & $7.1 \%$ & $38.1 \%$ & $21.4 \%$ & $16.7 \%$ & $16.7 \%$ & $100.0 \%$ \\
\hline & Total & & Count & 4 & 29 & 28 & 15 & 9 & 85 \\
\hline & & & $\%$ within Region & $4.7 \%$ & $34.1 \%$ & $32.9 \%$ & $17.6 \%$ & $10.6 \%$ & $100.0 \%$ \\
\hline
\end{tabular}

This ties in to the issue of payment. The study was curious to find out how much users pay for Internet access. Again there were both gender and regional variations. More women indicated paying a lower amount for the use of the café than men, while more men indicated paying a higher amount for the use of the Internet than women. This implies that the higher the amount to 
be paid for the service the lower the female patronage and vice-versa. This signals the need to subsidize the fee for the use of Internet services to enable more women to utilize the services. From the results $18.8 \%$ females and $8.9 \%$ males indicated paying GH $\varnothing .0 .50$ (US\$0.50) and $28.1 \%$ of the females as against $12.5 \%$ of the men indicated that they pay GH $\phi 1.00$ (US\$1.00) for the use of the Internet per hour. As the amount increased to GH 1.20 (US\$1.20), 30.8\% of the men and none of the women indicated that they pay for the same service. The rest of the respondents indicated to pay below GHф 0.50 (US\$0.50).

Respondents were asked what they use the Internet for. As shown in Table 5, more females than males indicated they use the Internet for sending e-mails only $(37.8 \%$ against $25 \%)$ and chatting with friends only (15.6\% versus $6.8 \%$ ). Specifically, $55 \%$ of females in the northern regions use it for emails only, $26 \%$ only for chatting, and very few do anything else compared with the other gender or region combinations. In terms of multiple use of the Internet the women from the deprived regions formed the least percentage of 11.9. The men formed the highest percentage (over $42 \%$ ) of those who use the Internet for emails, chatting with friends, and doing other things. They were followed by women from the endowed region, who formed $35.6 \%$.

\section{Table 5: Uses of the Internet}

\section{Region * What do you use the Internet for? Crosstabulation}

\begin{tabular}{|c|c|c|c|c|c|c|c|c|}
\hline \multirow[b]{2}{*}{ Sex } & & & & \multicolumn{4}{|c|}{ What do you use the Internet for? } & \multirow[b]{2}{*}{ Total } \\
\hline & & & & $\begin{array}{l}\text { Send } \\
\text { emails only }\end{array}$ & $\begin{array}{c}\text { Chat with } \\
\text { friends }\end{array}$ & Other & $\begin{array}{l}\text { All of the } \\
\text { above }\end{array}$ & \\
\hline \multirow[t]{6}{*}{ Male } & Region & Northern & Count & 11 & 7 & 17 & 26 & 61 \\
\hline & & & $\%$ within Region & $18.0 \%$ & $11.5 \%$ & $27.9 \%$ & $42.6 \%$ & $100.0 \%$ \\
\hline & & Greater Accra & Count & 22 & 2 & 17 & 30 & 71 \\
\hline & & & $\%$ within Region & $31.0 \%$ & $2.8 \%$ & $23.9 \%$ & $42.3 \%$ & $100.0 \%$ \\
\hline & Total & & Count & 33 & 9 & 34 & 56 & 132 \\
\hline & & & $\%$ within Region & $25.0 \%$ & $6.8 \%$ & $25.8 \%$ & $42.4 \%$ & $100.0 \%$ \\
\hline \multirow[t]{6}{*}{ Female } & Region & Northern & Count & 23 & 11 & 3 & 5 & 42 \\
\hline & & & $\%$ within Region & $54.8 \%$ & $26.2 \%$ & $7.1 \%$ & $11.9 \%$ & $100.0 \%$ \\
\hline & & Greater Accra & Count & 11 & 3 & 17 & 17 & 48 \\
\hline & & & $\%$ within Region & $22.9 \%$ & $6.3 \%$ & $35.4 \%$ & $35.4 \%$ & $100.0 \%$ \\
\hline & Total & & Count & 34 & 14 & 20 & 22 & 90 \\
\hline & & & $\%$ within Region & $37.8 \%$ & $15.6 \%$ & $22.2 \%$ & $24.4 \%$ & $100.0 \%$ \\
\hline
\end{tabular}

Respondents were questioned whether they were aware of search engines such as Google. For those who responded that they were aware of search engines such as Google, the men were leading the women: $72 \%$ as compared to $46.2 \%$ of the women. Disaggregated results show that of those who said they were aware of search engines, men from the endowed region topped the list with $91.4 \%$, followed by women from the endowed region $(88.7 \%)$, then men from the deprived regions $(57.8 \%)$. and lastly women from deprived regions $(27.1 \%)$. The regional and gender disaggregated data shows that urbanization has a possible effect on one's exposure to the different ICT applications.

Probably as a result of the gender and time factor, frequency of usage of the search engines was found to be higher among the men of both the endowed and deprived regions than their female counterparts. Over $40 \%$ of the men and $35.1 \%$ of the women indicated that they use the search engines once a week, while $23.2 \%$ of the men and $18.2 \%$ of the women use the search engines more than thrice a week. For occasional users, women were more than the men, thus $3.9 \%$ women and $2.4 \%$ men. Details are in Table 6. 
Table 6: Times of Usage of Search Engines

How often do you use the search engines per week?

\begin{tabular}{|c|c|c|c|c|c|c|c|c|c|}
\hline \multirow[b]{2}{*}{ Sex } & & & & \multicolumn{5}{|c|}{$\begin{array}{l}\text { How often do you use the search engines } \\
\text { per week? }\end{array}$} & \multirow[t]{2}{*}{ Total } \\
\hline & & & & $\begin{array}{l}\text { Occa- } \\
\text { sional }\end{array}$ & Once & Twice & Thrice & $\begin{array}{l}\text { More } \\
\text { than } \\
\text { Thrice }\end{array}$ & \\
\hline \multirow[t]{6}{*}{ Male } & Region & Northern & Count & 0 & 22 & 16 & 7 & 9 & 54 \\
\hline & & & $\%$ within Region & .0 & $40.7 \%$ & $29.6 \%$ & $13.0 \%$ & $16.7 \%$ & $100.0 \%$ \\
\hline & & $\begin{array}{l}\text { Greater } \\
\text { Accra }\end{array}$ & Count & 3 & 29 & 12 & 7 & 20 & 71 \\
\hline & & & $\%$ within Region & $4.2 \%$ & $40.8 \%$ & $16.9 \%$ & $9.9 \%$ & $28.2 \%$ & $100.0 \%$ \\
\hline & Total & & Count & 3 & 51 & 28 & 14 & 29 & 125 \\
\hline & & & \% within Region & $2.4 \%$ & $40.8 \%$ & $22.4 \%$ & $11.2 \%$ & $23.2 \%$ & $100.0 \%$ \\
\hline \multirow[t]{6}{*}{ Female } & Region & Northern & Count & 0 & 10 & 15 & 3 & 2 & 30 \\
\hline & & & $\%$ within Region & $.0 \%$ & $33.3 \%$ & $50.0 \%$ & $10.0 \%$ & $6.7 \%$ & $100.0 \%$ \\
\hline & & $\begin{array}{l}\text { Greater } \\
\text { Accra }\end{array}$ & Count & 3 & 17 & 6 & 9 & 12 & 47 \\
\hline & & & $\%$ within Region & $6.4 \%$ & $36.2 \%$ & $12.8 \%$ & $19.1 \%$ & $25.5 \%$ & $100.0 \%$ \\
\hline & Total & & Count & 3 & 27 & 21 & 12 & 14 & 77 \\
\hline & & & $\%$ within Region & $3.9 \%$ & $35.1 \%$ & $27.3 \%$ & $15.6 \%$ & $18.2 \%$ & $100.0 \%$ \\
\hline
\end{tabular}

As to whether they were aware that ICT could enhance their knowledge in any area of their choice, $90.7 \%$ of the males and $81 \%$ of the females responded positively. There were no significant regional and gender variations on this issue. This implies that though the level of usage is relatively low, knowledge appears to be very high.

\section{Ownership of Personal Computers and Payment for Internet Services}

Results on ownership of personal computers varied across regions and gender. Probably following economic trends, $48.2 \%$ of the males and $24.1 \%$ of females from the endowed regions and $22.1 \%$ of males and $16 \%$ of females from the deprived regions responded that they had personal computers. A follow up question sought to find out whether respondents who do not have a personal computer, would like to own one. From the results (Table 7) $98.4 \%$ of the males and $97.1 \%$ of the females said they would like to own a personal computer. On the regional breakdowns, $100 \%$ of males from the deprived regions, $97.6 \%$ of the females from the endowed region, $97 \%$ of those from the deprived regions, and $95.7 \%$ of males from the endowed region indicated that they would like to own a personal computer. It is clear that again, gender is not an inhibiting factor to the desire to own a personal computer. 
Table 7: Ownership of personal computer

Region * If no, would you like to own one? Crosstabulation

\begin{tabular}{|c|c|c|c|c|c|c|}
\hline \multirow[b]{2}{*}{ Sex } & & & & \multicolumn{2}{|c|}{$\begin{array}{c}\text { If no, would you like to } \\
\text { own one? }\end{array}$} & \multirow[b]{2}{*}{ Total } \\
\hline & & & & Yes & No & \\
\hline \multirow[t]{6}{*}{ Male } & Region & Northern & Count & 78 & 0 & 78 \\
\hline & & & $\%$ within Region & $100.0 \%$ & $.0 \%$ & $100.0 \%$ \\
\hline & & Greater Accra & Count & 44 & 2 & 46 \\
\hline & & & $\%$ within Region & $95.7 \%$ & $4.3 \%$ & $100.0 \%$ \\
\hline & Total & & Count & 122 & 2 & 124 \\
\hline & & & $\%$ within Region & $98.4 \%$ & $1.6 \%$ & $100.0 \%$ \\
\hline \multirow[t]{6}{*}{ Female } & Region & Northern & Count & 96 & 3 & 99 \\
\hline & & & $\%$ within Region & $97.0 \%$ & $3.0 \%$ & $100.0 \%$ \\
\hline & & Greater Accra & Count & 40 & 1 & 41 \\
\hline & & & $\%$ within Region & $97.6 \%$ & $2.4 \%$ & $100.0 \%$ \\
\hline & Total & & Count & 136 & 4 & 140 \\
\hline & & & $\%$ within Region & $97.1 \%$ & $2.9 \%$ & $100.0 \%$ \\
\hline
\end{tabular}

Considering the potential of Internet connectivity, respondents were asked whether they would like to have connection in their schools, workplace, or home. There were no significant differences across gender and location. A total of $94 \%$ of the men and $93.6 \%$ of the women responded in the positive. Maybe as a result of their high interest in the Internet, which was reflected in their duration of stay on the Internet, $98 \%$ of the men from the deprived regions took the lead, followed by their female counterparts with $94.1 \%$, then women in the endowed region with $92.3 \%$, with the least being men from the endowed region at $90.4 \%$. Interestingly, the desire to get connected was slightly higher among both males and females in the deprived regions than their counterparts in the endowed regions who may probably have had the exposure to the potential of the Internet and would want to utilize it fully. It could also be that the majority of the respondents from the endowed region already have connectivity and, therefore, will not need the service, especially if it will attract an extra fee.

To check the commitment of respondents, they were asked whether they would be willing to pay a flat fee of GH $\notin 20$ - 30 (approximately US\$20 - 30) per month for Internet connection. Table 8 shows that the percentage of the women from the deprived regions who were willing to pay was higher $(66.4 \%)$ than their counterparts in the endowed regions $(57.1 \%)$. The men from the endowed region however topped the entire list with $71.6 \%$. The significant observation is that over $66 \%$ of both males and females from the deprived regions are willing to invest GH $₫ 20-30$ per month for an Internet connection. 
Table 8: Payment for Internet connection

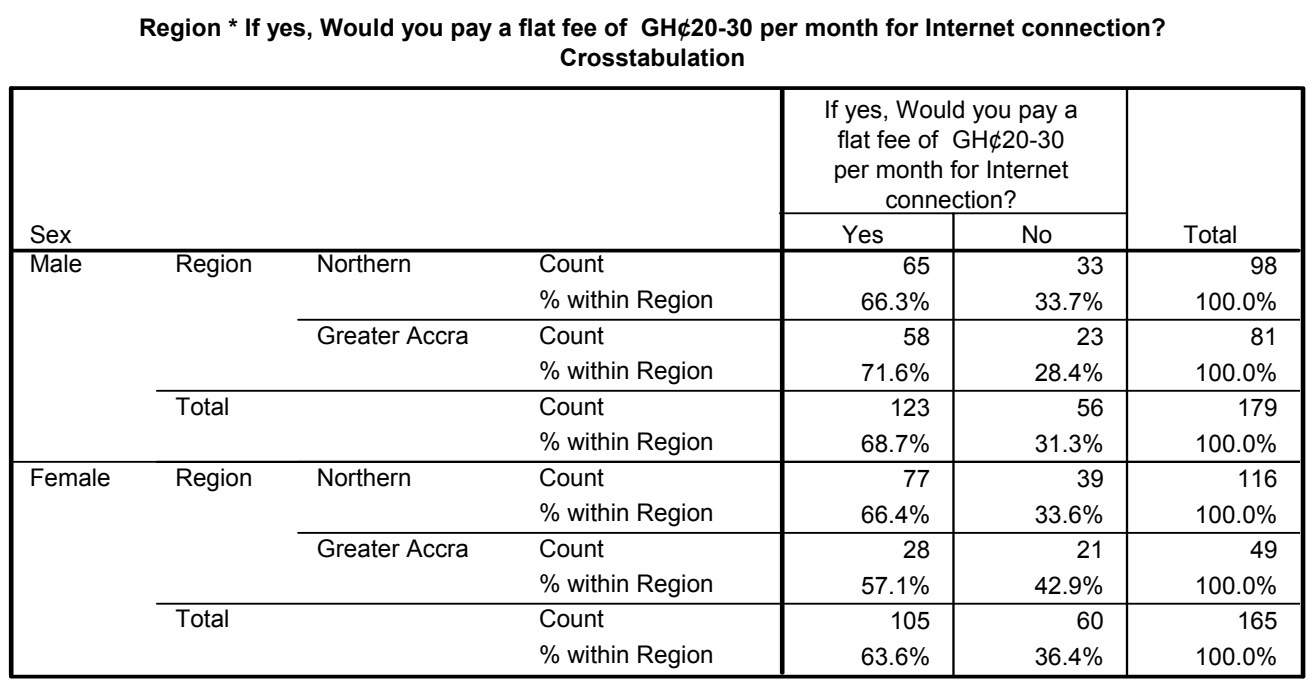

One could deduce from the results on knowledge and usage of ICT applications among men and women in endowed and deprived regions of Ghana that, generally, the learners are privately utilizing ICT facilities to some extent in spite of the limited infrastructural developments. This gives a clue that given the opportunity and support, both male and female distance learners in even underserved areas will utilize technology-mediated educational activities.

\section{Conclusion}

This paper has looked at the provision of distance learning in Ghana, a developing country in Sub-Saharan Africa, and the challenges which ICT could be used to address in spite of the limited infrastructural development in the sub-region. The literature review has shown that telecommunication, most especially mobile telephony, is increasing at a great rate in sub-Saharan Africa.

Focusing on distance learning students, the field survey has revealed that distance learners, males and females from both deprived and endowed areas in Ghana, have a fair idea of ICT and utilize it to some extent. Usage of the Internet is also relatively high among them, and over $60 \%$ of them are willing to pay a fee for the provision of Internet connectivity. The ICT profile of the distance learners will no doubt serve as a good starting point for the utilization of basic ICT programs, such as e-mails, text messages, and phone contacts, to facilitate communication among the learners and the institutions. A website for providing detailed information, application and registration, uploading and downloading main content and supplementary readers and other services will also be very helpful. One may be surprised that such basic ICT applications are not being fully utilized in most distance learning programs in the country. Considering the remote areas in which most of the students stay, on-line communication could be the most convenient way of reaching the students. However, in doing this, one should be cautious of the peculiarities of and disparities between rural and urban communities and between male and female students. There is also the need to consider how to adapt global software and hardware to benefit the various categories of people in different communities around the globe.

\section{References}

Asraf, M. M., Swatman, P., \& Hanisch, J. (2007). Some perspectives on understanding the adoption and implementation of ICT interventions in developing countries. The Journal of Community Informatics, 3(4). Retrieved March 15, 2008, from http://ci-journal.net/index.php/ciej/article/view/297/387 
Bisnath, S. (2004). Towards a more equitable information society: How and why of gender mainstreaming. Third meeting of the Working Group on Gender Issues. Retrieved March 21, 2008, from http://www.itu.int/ITU-D/gender/events/3rdAnnualWGGIMeeting/documents/3-11.pdf

Bruce, D. W., Hagens, V., \& Ellis, K. (2007). Technology mediated learning: Building capacity in rural communities. The Journal of Community Informatics, 3(4). Retrieved March 15, 2008, from http://cijournal.net/index.php/ciej/article/view/334/381

Daly, J. (2003). ICT, gender equality and empowering women. Retrieved March 20, 2008, from http://topics.developmentgateway.org/ict/sdm/previewDocument.do $\sim$ activeDocumentId=622821

Denison, T., \& Johanson, G. (2007). Surveys of the use of information and communications technologies by community-based organizations. The Journal of Community Informatics, 3(2). Retrieved March 15, 2008, from http://ci-journal.net/index.php/ciej/article/view/316/356

GenARDIS. (n.d.). Gender and Agriculture/rural Development in the Information Society. Retrieved May 11, 2008, from http://www.apcwomen.org/genardis/

Ghana (2003). National Medium Term Private Sector Development Strategy 2004 - 2008, Vol. 1: Strategy. Retrieved May 11, 2008, from http://www.dfid.gov.uk/pubs/files/ghana/priv-sect-dev-strategy-ghana20042008.pdf

Ghana (n.d). Ghana's Education System. Retrieved April 14, 2008, from http://www.ghana.gov.gh/ghana/education reform 2007 glance.jsp http://www.ghana.gov.gh/schools and universities http://www.ghana.gov.gh/ghanas education system

GLSS 4. (2000). Ghana Living Standards Survey - Report of the Fourth Round. Ghana Statistical Service.

Gulati, S. (2008). Technology-enhanced learning in developing nations: A review. The International Review of Research in Open and Distance Learning, 9(1). Retrieved March 15, 2008, from http://www.irrodl.org/index.php/irrodl/article/view/477/1011

Hafkin, N. J. (2003). Joint UNECE/UNCTAD/UIS/ITU/OECD/EUROSTAT statistical workshop: Monitoring the information society: Data, measurement and methods - gender issues in ICT statistics and indicators, with particular emphasis on developing countries. Retrieved March 21 2008, from http://www.unece.org/stats/documents/ces/sem.52/3.e.pdf

Holloway, K., \& Savvina, C. (2008). Teaching with instructional television. International Journal of Instructional Technology and Distance Learning, 5(1), 17-24.

Huyer, S., \& Sikoska, T. (2003). Overcoming the gender digital divide - Understanding ICTs and their potential for the empowerment of women. INSTRAW Research Paper Series No.1. Retrieved March 21, 2008, from http://www.un-instraw.org/en/docs/gender_and_ict/Synthesis_Paper.pdf

Infoplease (n.d). Ghana. Retrieved March 10, 2008 from http://www.infoplease.com/ipa/A0107584.html

ITU. (2007). United Nations Conference on Trade and Development - Beyond WSIS. World Information Society Report.

James, T., Leinonen, E., Smith, R., \& Haataja, M-L., (2006). A manual of possible interventions to improve the situation of women in high-level ICTs in South Africa. Retrieved March 21, 2008, from http://women-in-ict.meraka.csir.co.za/images/b/b5/Manual_print.pdf

Koul, B. N., \& Kanwar, A. (2006). Perspectives on distance education: Towards a culture of quality. Commonwealth of Learning. Retrieved March 20, 2008, from http://www.col.org/colweb/site/pid/3992

Kwapong, O. A. T. F. (2007a). Assessing willingness to pay for information delivery among rural women in Ghana. International Journal of Emerging Technologies in Learning (iJET), 2(4), 70-76.

Kwapong, O. A. T. F. (2007b). Wide World in Uganda, CYP in Ghana - Lessons to share. Zimbabwe Journal of Educational Research, 19(3), 240 - 263. 
Kwapong, O. A. T. F. (2007c). Widening access to tertiary education for women in Ghana through distance education. Turkish Online Journal of Distance Education-TOJDE, 8(4), 65 - 79. Retrieved from http://tojde.anadolu.edu.tr/tojde28/articles/article 5.htm

Kyama, R., \& Waititu, J. (2008). ICT Changing the Fortunes of Rural Communities. Retrieved May 19, 2008, from http://www.elearning-africa.com/newsportal/english/news134.php

Mensah, S. K. E., \& Owusu-Mensah, F. (2002). Priorities and Strategies for Capacity Building in Tertiary Distance Education for Human Resources Development in Ghana. A final report prepared for the World Bank. Retrieved from http://siteresources.worldbank.org/EDUCATION/Resources/2782001099079877269/547664-1099079956815/Ghana_capacity_building_En02.pdf

Ministry of Local Government and Rural Development \& Environment (MLGRD). (2006). Ghana Districts. Retrieved from http://www.ghanadistricts.com/home/

NCTE. (2006). Statistics on Tertiary Education in Ghana. National Commission for Tertiary Education

North West women to further ICT skills. (2008). Retrieved March 20, 2008, from, http://allafrica.com/stories/200709110469.html

Primo, N. (2003). Gender issues in the information society. Retrieved March 21, 2008, from http://portal.unesco.org/ci/en/file_download.php/250561f24133814c18284feedc30bb5egender_issues.p $\underline{\mathrm{df}}$

Robinson, B. (2008). Using distance education and ICT to improve access, equity and the quality in rural teachers' professional development in western China. The International Review of Research in Open and Distance Learning, 9(1). Retrieved March 15, 2008, from http://www.irrodl.org/index.php/irrodl/article/view/486/1013

Sales, G., Al-Barwani, T., \& Miske, S., (2007). Prospects and challenges of an online teacher training project in Oman. International Journal of Education and Development using ICT, 4(1). Retrieved March 15, 2008, from http://ijedict.dec.uwi.edu/viewarticle.php?id=408\&layout=html

Siaciwena, R., \& Lubinda, F. (2008). The role of open and distance learning in the implementation of the right to education in Zambia, The International Review of Research in Open and Distance Learning, 9(1). Retrieved March 15, 2008, from http://www.irrodl.org/index.php/irrodl/article/view/481/999

UNESCO. (2007). EFA global monitoring report 2008 - Education for all by 2015 -Will we make it? London: Oxford University Press.

World Bank. (n.d). ICTs and gender-evidence from OECD and non-OECD countries. Retrieved March 21, 2008, from http://go.worldbank.org/ZWPCWFSFV0

\section{Biography}

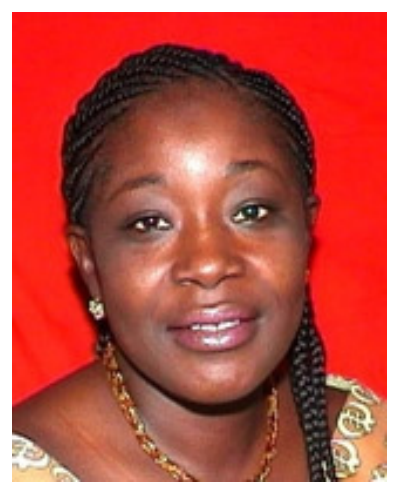

Olivia A. T. Frimpong Kwapong holds a PhD from the University of Ghana. She has studied as a special Doctoral Candidate at Harvard University. She is currently a lecturer at the Institute of Adult Education, University of Ghana. Her studies have focused in areas of gender and development, information and communication technologies, and open and distance learning. 